\title{
Global sustainability and responsibility in hotels and cruising industry
}

\author{
Carmen Vlasceanu \\ Bucharest University of Economic Studies, Bucharest, Romania \\ carmen_vlasceanu@yahoo.com \\ Iulian Tenie \\ Bucharest University of Economic Studies, Bucharest, Romania \\ iulian_tenie@yahoo.com \\ Oana Crismariu \\ Bucharest University of Economic Studies, Bucharest, Romania \\ oanadianacrismariu@gmail.com
}

\begin{abstract}
The tourism and hospitality industry is one of the largest industries in the world registering exponential growth over the past years. This study was conducted with the aim of highlighting various aspects of sustainable development from the hospitality industry perspective and the impact of tourism growth on the global touristic destinations. Attracting over 12 million passengers a year, the cruising industry alone contributes substantially by introducing every year a large number of mega size ships carrying over 5000 passengers on board. World renowned hotel chains have been expanding their regional presence providing services to millions of tourists and adventure seekers. The rapid development of the hospitality industry brings along undisputable challenges in environmental protection and natural landscape conservation. The methodology involves a review of the existing literature which concludes that around the world the situation is being addressed by the major players within the worlds' biggest industry at international conferences and various interactive panel discussions in their attempt to tackle the severe issues of tourism growth and creatively find innovative solutions to ensure environmental sustainability. Our research underlines the successful implementation of the environmental management standards within the cruising industry. The objectives of the global management standards are to ensure compliance in regulatory practices intended to preserve the environment through sustainable and responsible tourism. From this perspective, our analysis indicates that the hotel industry is in a formal adoption phase, posing consistency and implementation challenges across the industry and geographical regions. The overall findings of this research are briefly discussed.
\end{abstract}

Keywords: sustainable tourism, environmental protection, environmental impact, innovative sustainable solutions, corporate social responsibility, landscape conservation.

\section{Introduction: Sustainability and CSR in hospitality industry}

World Tourism Organization (WTO) forecasted that on a global scale by 2030 the tourism industry will employ approximately 1.8 billion people. Knowing this many countries focused towards investing in destination management to increase their afterwards earnings, particularly taking into consideration the determining factors affecting the global tourism (travelers, local communities, the environment, companies and other organizations (Shafiee, Ghatari, Hasanzadeh, \& Jahanyan, 2019).

In the last three decades, responsible destinations management has been the result of optimal strategies adopted based on sustainable development. Despite this fact, the changes in the hospitality industry, the socio-cultural complexity of the locals, the evolution of tourist 
destinations, the situation of national economies, but also the tourist tendencies violate the principles of sustainability (Gkoumas, 2019).

Tourism industry players (hoteliers, restaurant owners, travel agents, transport companies) argue that the practice of sustainable tourism is not their responsibility as far as governments and local authorities are concerned. However, they argue that social responsibility promotes sustainability, being linked in particular with ecology and environmental protection (Gkoumas, 2019).

PICBE | 307

This paper consists of three parts: the first section presents an overview of sustainability from the global perspective, the second part provides an examination of the sustainability in hotels and the final part provides an introspective glance at the sustainability within the cruising industry.

The purpose of this article is to analyze sustainability in the global context in addition to highlighting different aspects in support of sustainable tourism in different sectors of the hospitality industry.

\section{Overview of sustainability from the global perspective}

"Sustainability" as a term was first mentioned in 1713 and it can be understood as a way of continuously managing the resources implying sustainable development.

The World Tourism Organization (WTO) defines tourism as a "social, cultural and economic phenomenon related to the movement of people to places outside their usual residence for personal or professional reasons." Therefore, tourism has an influence on economic, social, cultural and cultural aspects and the dimensions of the environment. Tourism is one of the sectors that contributes the most to the economies of the regions, which have also registered one of the biggest increases of the last decades. As a result, most governments promote tourism as a source of income as the tourism industry generates economic wealth in the locations visited by tourists.

The young generations whose future will be impacted by the global tourism increase seem to be more inclined to welcoming new initiatives and sustainable operations that are imperatively necessary at every industry level, aiming towards achieving sustainable destinations' development. There have been many theories and definitions elaborated by the academia and the research community pertaining to the meaning of sustainable tourism while attaining business sustainability.

The idea of sustainability as a business opportunity has led to the formation of organizations such as the Sustainability Consortium of the Society for Organizational Learning, the Institute of Sustainable Business and the World Council for Sustainable Development. One consequence was the inclusion of sustainability in the company's business strategy. A concept used, introduced and addressed by Schaltegger and Wagner (2006), is sustainability performance management, which is a concept that requires a good management framework, which on the one hand, links social and environmental management with competitive strategy and business management, and on the other hand integrates information. Firms may have more goals when implementing sustainability in their actions, for example: increasing the efficiency of operations, reducing the impact on the environment, creating new business values, attracting new customers and creating sustainability-oriented innovations (Baumgartner and Rauter, 2017).

In the relevant published literature, also emerging as a common theory, being mostly utilized in the tourism field, as The World Tourism Organization (WTO) informed, tourism can be sustainable if we can afford ideologies, economical and managing processes. Literature review reflects that resources that can be correlated with the tourism tendencies are considered as a 
forecasting element, bringing benefits in socio-economic environment at macro dimensions. Through this kind of theories value can be added to the tourism business environment and enable the dreams to become reality: "Tomorrow will become performance" (Sangchumnong, 2018).

Sustainability-oriented innovations (SOI) are a broad concept, in which the focus is on the intended changes that companies make through their organization, processes, products and services in order to create sustainable and business value (Adams et al. ., 2016). In particular, sustainability-oriented business models are seen as an approach to addressing sustainability challenges at the systemic level (e.g. Betramello et al., 2013; Wells, 2013). Thus, the development of sustainability-oriented business models has gained high importance in the sustainability and innovation management in practice (Lüdeke-Freund et al., 2017). Sustainability-oriented business model refers to firm's plan for generating profits while voluntarily supporting the activities, which aim to create ecological and social value. In more detail, following the definition of Schaltegger et al. (2016, p.6): "it helps describing, analyzing, managing, and communicating (i) a company's sustainable value proposition to its customers, and all other stakeholders, (ii) how it creates and delivers this value, (iii) and how it captures economic value while maintaining or regenerating natural, social, and economic capital beyond its organizational boundaries."

The efficient increase of tourism sustainability can only be achieved by implementing certain tools and practices which are founded on two well determined goals. The first one refers to the reduction of pollution factors and all the aspects that affect the environment and the second refers to green energy and how it can replace the old "tools" leading to enhancing the efficiency of the processes having a less harmful characteristic. Thus the specialized organizations on these segments offer viable solutions that can be implemented successfully and their results be defined by high performance scaffolding (Reid, Johnston, \& Patiar, 2017).

In the last decade particularly, people realized the opportunities posed by the cruising industry benefiting the locals as well as the tourists and as a result, the number of ports increased around the globe. As a consequence, this kind of development was also harmful for a few parts of travel sector (Rosa-Jimenez, Perea-Medina, Andrade, \& Nebot, 2018).

A recent study highlighted the positive impact that the local communities have over the destination competitiveness. The tourism product is made up of local communities and their direct involvement in the process poses a great influence on the tourism development, it is clear that the race towards the sustainable development of tourism has an absolute need for successful management along with the continuous environmental protection of the destinations, the natural landscape conservation and its competitiveness. (Cucculelli \& Goffi, 2016). In an article recently published in Italy a few recommendations have been made for destinations to become more sustainable. Seven of them are related to sustainable tourism policy and management, such as: "control of tourism through national, regional or local tourism departments; facilitating the involvement of interested economic agents; careful observation of the impact of overtourism; investing in the educational system which prepares workers in the hospitality industry; the unitary approach of tourism, based on intersectoral relations; maximizing the impact on local communities, by establishing local economic links and granting a special importance to sociocultural problems, avoiding the negative social impact and promoting the authentic local culture". Three recommendations are related to sustainable infrastructure, tourists' responsibility and sustainable local environment. All of them are also significant parts of the tourist destination competitiveness (Goffi, Cucculelli, \& Masiero, 2019). 


\section{Examination of the sustainability in hotel industry}

The trend towards sustainable environment is growing stronger and is becoming more visible in the hospitality industry, where hotel managers or restaurant owners develop eco-friendly initiatives and invest in technologies and solutions that reduce the carbon footprint. Goldstein and Primlani, 2012 suggests that "the past several decades have seen a growing awareness among hoteliers and investors regarding the environmental and social impacts of hotel development and operations". The more a hotel consumes less resources and implements self-sustainability programs, such as collecting rainwater, using solar panels or recycling waste, systems that monitor and reduce electricity consumption, the closer to the idea of sustainability the hotel gets. In the near future, one of the tourist's main selection criteria regarding the accommodation units will refer to the eco-friendliness degree it offers.

Sustainability is often seen as an interaction between three integrated elements: environment (ecology), economy and society - as presented by the dimensions of the Three Basic Pillars Model (Center for Environmental Education, 2007). These three pillars have served in recent years as a common foundation for many sustainability standards and certification systems. Understanding the need for sustainable development in the hotel industry can be exemplified by analyzing the statements and actions of some of the most important hotel groups (Jones, P., Hillier, D., Comfort, D., 2013): Marriott believes that "investing in sustainable development and innovative conservation initiatives [.. .] that will provide long term solutions to critical social and environmental issues" (Marriott, 2012,) and to Wyndham Worldwide "commitment to sustainability, which by definition means meeting the needs of the present without compromising the ability of future generations to meet their own needs" and the company outlines how it is "delivering Triple Bottom Line benefits" by focusing on "people", "profits" and the "planet" (Wyndham Worldwide, 2011).

In the case of the Hilton hotel chain, the mission of sustainability is "to benefit this and future generations by actively managing our business through the lens of sustainability" and stresses that "sustainability is now a critical performance measure for our business". IHG). Iberostar presents "concern for the economic, human and social development of the communities where the company has a presence" and its "firm commitment to the preservation of the environment and respect for wildlife in all the destinations in which we operate" (Iberostar, 2012).

Wyndham Worldwide, for example, presents the risks posed by "rising costs of fuel, energy and water", and "increased regulatory legislation which may inhibit growth and negatively impact on operational profitability" (Wyndham Worldwide, 2011). Hyatt announced that they have set specific targets for reducing energy consumption by $25 \%$, water consumption by $20 \%$, greenhouse gas emissions by $25 \%$ and waste sent to landfill by $25 \%$ by 2015 . The company reports also that it can pursue these goals with a web-based tracking system that allows it to "benchmark our performance and to drive improvement. ." Wyndham Worldwide considers that "energy consumption and the resulting greenhouse gas emissions" as the "most material environmental aspects", and the company has set a long-term goal: to reduce carbon dioxide emissions by up to $20 \%$. in 2020 (Wyndham Worldwide, 2011 ). Also, the InterContinental Hotels Group (2012), for example, suggests that "many parts of the world are already experiencing freshwater stress and that climate change is expected to exacerbate these issues."

The company recommends that hotels in temperate areas conserve between $10 \%$ and $20 \%$ of water use and report a variety of water conservation initiatives, including efficient water 
installations and appliances, water collection, water treatment and reuse and irrigation.

Marriott argues that "integrated global environmental strategy that improves energy efficiency, conserves water, builds more sustainable hotels and supports high level projects that reduce greenhouse gas emissions" (Marriott, 2012,).

Best Western (2012) argues that its hotels "do everything from having in-room recycle bins and linen re-use programs to geothermal and solar powered hotels that actually sell power back to the grid" and that "every hotel in North America is required to have a green program in place", which could include "anything from using recycled paper and installing low-flow shower heads to full participation with national or international eco-labelling programs". Hyatt, for example, argues that procurement strategies include shampoo and lotion packing in 100 percent recycled plastic bottles, using 100 percent recycled carpets, and offering durable menu options. Marriot relates to collaborating with suppliers to "advance the sustainability of their products to conserve energy, reduce water use, increase waste diversion and to include more sustainable materials" and lists its achievements, which include "recycled content key cards, Eco-Smart pillows, room ready towels, recycled material pens, low VOW paint, biodegradable laundry bags, low energy light bulbs and coreless toilet paper". Under the banner "Sustainability in Our Kitchens" (Marriott, 2012).

A fundamental commitment to hotel guests and a concern for their health, safety and security loom large in the selected companies' sustainability agendas (Jones, P., Hillier, D., Comfort, D., 2013). Jumeirah, for example, reports "we develop products and services based on guest needs and preferences which we gather and store in secure guest profiles" ( Jumeirah, 2008, p. 14) and that it "designs and delivers repeat guest amenity programs". The company also stresses that its staff are "trained in fire, high level security threat scenarios and emergency evacuations" ( Jumeirah, 2008,). Marriott claims that its "brands remain strong as a result of superior customer service" and reports that its guest loyalty program has "38 million members" (Marriott, 2012). Customer feedback is seen to be critical to successful customer service and to customer loyalty, and the company reports on the high guest satisfaction scores emanating from this process.

The top ten hotel chains generally report on their links with the local communities and on their donations to charity as important elements in their sustainability commitments. Marriott, for example, reports on its "Spirit To Serve Our Communities" (Marriott, 2012) strategy, which in 2011 delivered some $\$ 23 \mathrm{~m}$ in cash and kind donations to organizations worldwide. The company's employees raised a further $\$ 4.9 \mathrm{~m}$ for their local communities through companysponsored events and volunteered some 400,000 hours valued at $\$ 9.4 \mathrm{~m}$. The company also reports on its work in "addressing housing and hunger needs", particularly "in times of disaster", on "aiding sick and impoverished children", and emphasizes its long-term relationship with a number of international aid agencies (Marriott, 2012,).

Best Western describes itself as "a company that cares", and it outlines its work in helping poorer communities by providing access to food, clean water supplies, health care and education. Hilton claims that "celebrating cultures is at our core" and that it looks to "celebrate and preserve the unique cultural heritage of the communities where we operate" (Hilton, 2012). Another example is the AccorHotels group, started the Planet 21 project since 2011, which includes a series of initiatives such as selective waste collection, stopping food waste, optimizing and reducing water consumption or promoting balanced menus in hotel restaurants. In 2008, after an extensive process of renovation and modernization, the Vega hotel in the Black Sea reopened, 
promoting the image of "eco-hotel". In the same year, the accommodation unit obtained the Blue Flag ecological certificate for the beach it owns, and since 2013 it has become the first hotel in Romania that exclusively uses renewable energy.

When it comes to restaurants, it is important that they collaborate with local producers and use organic and seasonal ingredients. An example of a sustainable restaurant is Relae, opened by the Sicilian Christian Francesco Puglisi in Copenhagen, which has received numerous awards due to its eco policy. The restaurant has a Michelin star and is trying to find solutions to deliver high quality dishes at an affordable price by using a minimum of resources. Thus, the bread is delivered on bicycles, the wine is of its own production, the waste of food has been eliminated, and the uniforms of cooks and waiters are made of a special material, which does not require frequent washing.

\section{Examination of the sustainability in cruising industry}

The increasing global concerns trending within the travel and hospitality industry over the past few years have had a transformational effect on the industry itself as more and more players on the market adjust their business policies towards environment sustainability and protecting the landscapes of the touristic destinations.

Popular travel destinations struggle with the high number of tourists affecting the ability to enjoy the area, posing challenges in the long term by causing irreversible damage to ecosystems and significant landmarks.

In their quest for relevance on the global travel market, some of the cruise operators position their strategies towards acquiring new generation ships featuring liquified natural gas, a composition of methane and ethane gas known as LNG. "With 11 LNG-fueled ships on order, Carnival Corporation has the largest orderbook of green ships in the cruise industry" (Cruise Industry News, Sep. 28 2018).

The environmental performance is a priority for the majority of cruise lines as new approaches are being employed towards increasing energy efficiencies and reducing the level of emissions. According to the International Organization for Standardization (ISO 14001:2004-E, 2004) within the organization's structured management system periodical audits are required to be performed. However, the major cruise operators in the industry, by their own choice adhere to the regulatory compliance ensuring that the environmental reviews and audits are effectively assessed by the responsible authorities.

"Technical competence, impartiality, and independence" (Cruise Industry News, Aug. 21 2006) represent high standard elements ensured by the ISO 14001 certification, widely preferred by the cruise operators to include it in their quality assurance management system.

At the shipboard level, the ISO 14001 standards materialize in intricate technical operations based on raw data collection and automatically processing by a series of predefined sequence of operations and algorithms.

The statistics resulted from each vessel are later on fleet wide centralized and utilized to assess and evaluate the performance on various criteria as to accurately determine the registered numerical values versus the proposed goals and parameters to be attained.

The MARPOL convention adopted in 1973 by the IMO stipulates a series of regulatory measures and was designed to serve as an "instrument for the prevention of marine pollution 
from ships", universally adopted and regarded by all the actors in the marine and cruising industry (Australian Government, Jan. 2018).

The table below presents an overview of the air emission levels recorded aboard the CCL's entire fleet, over a three years period (Carnival Cruise Lines, 2018).

Table 1. Cruise line air emissions statistics registered fleetwide between 2016-2018:

PICBE | 312

\begin{tabular}{|l|l|l|l|l|}
\hline & Units & $\mathbf{2 0 1 6}$ & $\mathbf{2 0 1 7}$ & $\mathbf{2 0 1 8}$ \\
\hline Emissions Type & Number & $\mathbf{1 0 2}$ & $\mathbf{1 0 3}$ & $\mathbf{1 0 4}$ \\
\hline $\begin{array}{l}\text { Ship Fugitive Refrigerant } \\
\text { Releases1 }\end{array}$ & Kilograms & 117,936 & 107,153 & 97,628 \\
\hline $\begin{array}{l}\text { Ship Ozone Depleting } \\
\text { Substances (ODS) Emissions1,3 }\end{array}$ & Kg CFC-11e & 10,292 & 318 & 1,331 \\
\hline $\begin{array}{l}\text { Total Sulfur Oxides (SOx) } \\
\text { Emissions4 }\end{array}$ & Metric Tons & 98,089 & 99,622 & 98,543 \\
\hline $\begin{array}{l}\text { Sulfur Oxides (SOx) Emissions } \\
\text { Rate }\end{array}$ & Kg SOx/NM & 10.4 & 10.3 & 10.2 \\
\hline $\begin{array}{l}\text { Total Nitrogen Oxides (NOx) } \\
\text { Emissions5 }\end{array}$ & Metric Tons & 253,532 & 257,665 & 258,410 \\
\hline $\begin{array}{l}\text { Nitrogen Oxides (NOx) } \\
\text { Emissions Rate }\end{array}$ & Kg NOx/NM & 27.0 & 26.8 & 26.8 \\
\hline $\begin{array}{l}\text { Total Particulate Matter (PM2.5) } \\
\text { Emissions6 }\end{array}$ & Metric Tons & 2,092 & 2,099 & 2,086 \\
\hline $\begin{array}{l}\text { Particulate Matter (PM2.5) } \\
\text { Emission Rate }\end{array}$ & Kg PM/NM & 0.22 & 0.22 & 0.22 \\
\hline
\end{tabular}

Source: Carnival Cruise Lines - https://www.carnivalcorporation.com/transparency-and-reporting/sustainabilityreports

The values captured in the above table exposes along the three years studied, 2016 through 2018, of which it can easily be observed the decreasing trend registered in the levels of waste. The report issued by Carnival Cruise Lines lists a series of potential health hazards emissions associated with gases such as nitrogen oxides (NOx), sulphur oxides (SOx), and ship ozone depleting substances (ODS) Emissions1,3 such as carbon dioxide (CO2) which are found in the exhausts of marine diesel engines.

Our research findings conclude that the evolution of the above indicators represents a compelling evidence in the challenging task of achieving sustainability efficiency aboard the mega-cruise ships. The cruise line's commitment in the development of a new environmental approach and their example of good practice is conferred by each and every ship's compliance with ISO 14001 environmental standards.

As the global natural landscape is increasingly affected by environmental degradation, the trend of the cruising industry is to "adopt the ISO 14001 standards in conjunction with the International Safety Management System, ideally because both systems go hand-in-hand with the implementation of a maritime compliance program" (Bryant, D., Carr D., William A., Thomas L, 1997).

The adherence to the rigorous rules along with the newest techniques of reducing the production of oily waste and sludge on board the vessels are a clear indication that the policies 
implemented are working efficiently towards decreasing the waste levels. Usage of clean and treated fuel besides being an environmentally friendly practice, also generates less sludge and harmful substances.

\section{Conclusions}

The cruising industry seems to have taken the lead in their commitment of adopting sustainable business practices and focused their goals on reducing the environmental footprint, making a real sustainable impact on the visited ports and their local communities.

In their approach to sustainability the cruising industry is actively engaged in developing technologies and fuels to reduce emissions both at sea and in ports. Outlining their position and strategies the major cruise operators are allocating resources into research and development of programs addressing the key sustainability topics while enhancing the health, safety and security of the tourists as well as the inhabitants of the exotic destinations visited.

As the majority of cruise companies are committed to employ new technologies in order to reduce the $\mathrm{CO} 2$, and other emissions with the daring target of zero emissions in the future, throughout the leading cruise brands major investments have been deployed working along with research institutes and shipyards to achieve the goal of sustainable tourism and ultimately help preserve the ecosystem, enhance the marine biodiversity and equally support communities that solely rely on the sea environments.

Nevertheless, the overcrowding issues remain as the local residents' everyday lives are being impacted by the visitor's traffic and the communities are becoming increasingly concerned about cruise ships air emissions when docked in ports.

Cruise operators' reputation and their success depends on having sustainable and transparent operations to tackle the environmental issues while ensuring business continuity.

Although by 2050 IMO regulations call for a 50\% drop in $\mathrm{CO} 2$ emissions, global cruise companies are focused on achieving the ultimate zero impact on climate by the efficient implementation of environmental management standards ISO 14001 along with the development of new technologies, whose objective is eliminating $\mathrm{CO} 2$ emissions on all ships, ensuring the carbon neutral independent functionality while at sea and in ports.

On a global scale all the sectors of the tourism and hospitality industry have been shifting their perspective towards embracing sustainability thus becoming increasingly aware of their social responsibility regarded as they key to business success.

In order to reduce the negative impact on the environment many hotel organizations have been adopting policies and practices targeting waste prevention and energy reduction, recycling and re-using grey water and reducing the overall carbon footprint.

Challenges exist as cruise line operators and hotel chains are concerned about achieving the thin balance between running a profitable and yet sustainable business whilst adhering to the latest practices and innovative sustainable solutions to help create a positive impact on the natural environment and ensure the well-being of the global ecosystem.

\section{References}

Adams, R., Jeanrenaud, S., Bessant, J., Denyer, D., Overy, P. (2016). Sustainability-oriented innovation: a systematic review. International Journal of Management Reviews, 18(2), 180-205. 
Baumgartner, R.J., Rauter, R. (2017). Strategic perspectives of corporate sustainability management to develop a sustainable organization. Journal of Cleaner Production, 140, 81-92.

Beltramello, A., Haie-Fayle, L., Pilat, D. (2013). Why New Business Models Matter for Green Growth. OECD Green Growth Papers. Paris: OECD Publishing.

Bryant, D., Carr D., William A., Thomas L (1997) - Devising a Compliance Strategy Under the

PICBE | 314 ISO 14000 International Environment Management Standards, 15 PACE ENVTL. L. REV. 85, 87.

Carnival Cruise Lines, 2018 - Sustainability from Ship to Shore, retrieved from http://carnivalsustainability.com/download-files/2018-carnival-sustainability-full.pdf

Cruise Industry News, (Aug 21, 2006) - Lloyd's Register Quality Assurance Issues ISO 14001 cert. to HAL and Windstar, retrieved from http://www.cruiseindustrynews.com/index.php?option=com_content\&task=view\&id $=125$ $\&$ Itemid $=58$

Cruise Industry News, (Sep. 28, 2018) New Carnival LNG Ships to Drive Fuel Efficiency retrieved from https://www.cruiseindustrynews.com/cruise-news/19717-new-carnival-lngships-to-drive-fuel-efficiency.html

Cucculelli, M., \& Goffi, G. (2016). Does sustainability enhance tourism destination competitiveness? Evidence from Italian Destinations of Excellence. Journal of Cleaner Production, 370-382.

Gkoumas, A. (2019). Evaluating a standard for sustainable tourism through the lenses of local industry. Heliyon.

Goffi, G., Cucculelli, M., \& Masiero, L. (2019). Fostering tourism destination competitiveness in developing countries: The role of sustainability. Journal of Cleaner Production, 101-115.

Goldstein, K.A. and Primlani, R.V. (2012), "Current trends and opportunities in hotel sustainability”, available at: www.hospitalitynet.org/news/4054752.html

Int'1 Org. for Standardization, ISO 14001:2004, (2004).

Cucculelli, M., \& Goffi, G. (2016). Does sustainability enhance tourism destination competitiveness? Evidence from Italian Destinations of Excellence. Journal of Cleaner Production, 370-382.

International Maritime Organization, 2014 - GHG emissions from international shipping, retrieved from: http://www.imo.org/en/OurWork/Environment/PollutionPrevention

Jones, P., Hillier,D., Comfort, D., Sustainability in the global hotel industry (2013). International Journal of Contemporary Hospitality Management Vol. 26 No. 1, 2014 Emerald Group Publishing Limited

Jumeirah (2008), “Corporate social responsibility”, available at: http://media.jumeirah.com/

Hilton (2012), "Travel with purpose”, available at: www.hiltonworldwide.com/corporateresponsibility/

Hyatt (2012), “Global corporate responsibility program”, available at: http://thrive.hyatt.com/ aboutHyattThrive.html

Iberostar (2012), "Social responsibility", available at: www.iberostar.com/en/socialresponsibility. 
Lüdeke-Freund, F., Freudenreich, B., Saviuc, I., Schaltegger, S., Stock, M. (2017). SustainabilityOriented Business Model Assessment - A Conceptual Foundation, In: Carayannis, E., Sindakis, S. (Eds.). Analytics, Innovation and Excellence-Driven Enterprise Sustainability. Houndmills, Palgrave, 169-206.

Marriott (2012), "2011-2012 Sustainability Report”, available at:

www.marriott.com/Multimedia/PDF/CorporateResponsibility/MarriottSustainabilityRepo

PICBE | 315 rt 2011and2012condensed4MB. pdf

Reid, S., Johnston, N., \& Patiar, A. (2017). Coastal resorts setting the pace: An evaluation of sustainable hotel practices. Journal of Hospitality and Tourism Management, 11-22.

Rosa-Jimenez, C., Perea-Medina, B., Andrade, M. J., \& Nebot, N. (2018). An examination of the territorial imbalance of the cruising activity in the main Mediterranean port destinations: Effects on sustainable transport. Journal of Transport Geography, 94-101.

Sangchumnong, A. (2018). Development of a sustainable tourist destination based on the creative economy: A case study of Klong Kone Mangrove Community, Thailand. Kasetsart Journal of Social Sciences, 1-8.

Schaltegger, S. and Wagner, M., 2006. Managing sustainability performance measurement and reporting in an integrated manner. Sustainability accounting as the link between the sustainability balanced scorecard and sustainability reporting. Sustainability Accounting and Reporting, 21, pp.681-697. [pdf] Available at: $<\mathrm{http}: / /$ link.springer.com/content/pdf/10.1007/978-1-4020-4974-3_30.pdf $>$ [Accessed 9 July 2013].

Shafiee, S., Ghatari, A. R., Hasanzadeh, A., \& Jahanyan, S. (2019). Developing a model for sustainable smart tourism destinations: A systematic review. Tourism Management Perspectives, 287-300.

Wells, P. (2013). Business Models for Sustainability. Cheltenham: Edward Elgar Publishing. Wyndham Worldwide (2011), "Wyndham Worldwide sustainability report”, available at: www. wyndhamworldwide.com/docs/ Final-Wyndham-Sustainability-Report-July-2011.pdf 